\title{
Mn-Fe Nanowires Towards Cell Labeling and Magnetic Resonance Imaging
}

\author{
Ken Cham-Fai Leung and Yi-Xiang J. Wang \\ Center of Novel Functional Molecules, Department of Chemistry and \\ Department of Diagnostic Radiology and Organ Imaging, Prince of Wales Hospital \\ The Chinese University of Hong Kong, Shatin, NT \\ Hong Kong SAR, P. R. China
}

\section{Introduction}

In the past two decades, our understanding in biology, materials science and nanotechnology has expanded rapidly. The inevitable intersection of these three disciplines has set in motion the development of an emerging research area, nanobiotechnology or nanobiomedical science, which offers exciting and abundant opportunities for discovering new processes and phenomena. In particular, the advances in the synthesis and characterization of nanoscale materials allow scientists to understand and control the interactions between nanomaterials (e.g., nanowires, nanofibers, nanoparticles, nanobelts or nanoribbons, and nanotubes) and biological entities (e.g., nucleic acid, proteins, or cells) at molecular or cellular levels. These advances promise major achievements in the life sciences. By way of an example, the research on magnetic nanomaterials (Skomski, 2003) has attracted a lot of attention because of their numerous applications including magnetic separation of biomolecules (Nam et al., 2003), as biocompatible contrast agents for magnetic resonance imaging (MRI) (Wang et al., 2001; Berry \& Curtis 2003; Pankhurst et al., 2003; Tartaj et al., 2003; Nitin et al., 2004; Lee et al., 2007), magnetic recording (Darques et al., 2009), spintronic devices and magnetic sensing (Thurn-Albrecht et al., 2000; Allwood et al., 2002; Redl et al., 2003). Relatively large, near-monodisperse spherical iron oxide $\left(\mathrm{Fe}_{3} \mathrm{O}_{4}\right.$, magnetite) nanoparticles with average core diameters of 200-1000 nm are commercially available (e.g., Feridex), some of them are used as contrast agents for in vivo clinical MRI. These relatively large magnetite nanoparticles can be obtained by a structural refinement process of bulk materials or a recrystallization from small nanoparticles. In respect to biological applications, the particles' surface is usually coated with dextran as a biocompatible, protective layer. Biodegradable magnetic nanoparticles can be labeled intracellularly towards cellular and molecular imaging, and also used for targeted drug carrier together with controlled release capabilities (Lübbe et al., 2001), and radio frequency therapy of tumours via hyperthermia (Fortin et al., 2007). There are indications that the size, shape, structure, and the functional surfaces (e.g., amine, hydroxyl, poly(ethylene glycol), etc.), texture and porosity of many biocompatible nanomaterials are important parameters which influence the rate of cell attachment, internalization, uptake and vascular dynamics (Corot et al., 2006; Wilhelm \& Gazeau 2008; Mitragotri \& Lahann 2009; Park et al., 2009).

Source: Nanowires Science and Technology, Book edited by: Nicoleta Lupu,

ISBN 978-953-7619-89-3, pp. 402, February 2010, INTECH, Croatia, downloaded from SCIYO.COM 
The properties of one-dimensional (1-D) nanowires toward biological systems are attracting increasing attention recently (Fang \& Kelley 2009; Cohen-Karni et al., 2009). Generally, nanomaterials having elongated shapes and correspondingly increased surface area are more effective in vivo due to the geometrically enhanced multivalent interaction between ligands and receptors (Mitragotri \& Lahann 2009). In comparison to the zero-dimensional nanoparticles, 1-D nanowires provide more parallel-aligned surface functionalities per molecular structure, which are suitable for multivalent molecular recognition on cell surfaces. Potential application of the magnetic nanowires may offer endothelium surface magnetic labeling because of their steric hindrance in passing into the extra-vascular space. Macrophage cells may take up the nanowires more rapidly than nanoparticles by their differences in mass. It is of current interest to investigate the cell labeling efficacy with 1-D nanomaterials, cytotoxicity, stability in different cell compartments, and fate of the materials. Recently, Park et al. reported 1-D magnetic nanoworms for in vivo tumor targeting (Park et al., 2009). Superparamagnetic iron oxide nanoworms that have a long dimension of $\sim 70 \mathrm{~nm}$ and thickness of $\sim 30 \mathrm{~nm}$ have been used for targeting xenograft tumors. The nanoworms exhibit superior in vivo tumor-targeting ability than nanoparticles (mean diameter $\sim 30 \mathrm{~nm}$ ). The authors conclude that the blood half-life of a targeting moleculesnanomaterial ensemble is a key consideration when selecting the appropriate ligand and nanoparticle chemistry for tumor targeting.

Although different magnetic nanowires have been fabricated by solution methods-a bottom-up approach (versus a top-down aprroach which produces nanostructures by refinement of bulk materials) (Xia et al., 1999; Stephanopoulos et al., 2005)-and characterized by various techniques (Whitney et al., 1993; Meier et al., 1996; Doudin et al., 1996; Ferré et al., 1997; Fert \& Piraux 1999; García \& Miltat 2002; Nielsch et al., 2002; Chen et al.(a), 2003; Chen et al.(b), 2003; Love et al., 2003; Ponhan \& Maensiri 2009), however, the effective preparation, cytotoxicity, as well as cell labelling efficacy of different cell types using relatively rigid, long magnetic nanowires have been seldomly investigated. Therefore, we have recently investigated rigid 1-D magnetic nanostructures as effective contrast agents for MRI, and discovered the preparation of Mn-Fe oxide nanowires with amine-functional peripheries, which are formed by a self-assembling organization of their corresponding small $\mathrm{MnFe}_{2} \mathrm{O}_{4}$ nanoparticles - a process of assembling approach using cystamine as the linker. This approach, which utilizes chemicals and supramolecular driving forces to arrange small components into an ordered conformation, represents an effective and inexpensive way to achieve more complex and functional nanoarchitectures. Herein, the properties of Mn-Fe nanowires with lengths ranging from 400-1000 nm and widths ranging from 8-35 $\mathrm{nm}$ for MRI contrast and the potential of macrophage cell uptake are also reported (Leung et al., 2008; Leung et al., 2009).

\section{Approach}

\subsection{Synthesis of the nanostructures}

Spontaneous organization of small individual nanostructures into large and well-defined nanowires, represents (Tang et al., 2002; Grubbs 2007) a facile way to obtain useful nanomaterials for magnetic devices (Hangarter et al., 2007; Wu et al., 2007). The key to prepare our target 1-D Mn-Fe nanowires for cell labeling and MRI contrast could be achieved in such a way that small building blocks $-\mathrm{MnFe}_{2} \mathrm{O}_{4}$ nanoparticles which were prepared by co-precipitation at elevated temperature (Sousa et al., 2001; Aquino et al., 2002; 
Deng et al., 2005), were rationally organized into Mn-Fe nanowires with larger lengths in relatively high yields. We have found out that suitable amount of linker - cystamine $\left(\mathrm{NH}_{2} \mathrm{CH}_{2} \mathrm{CH}_{2} \mathrm{~S}-\mathrm{SCH}_{2} \mathrm{CH}_{2} \mathrm{NH}_{2}\right)$ could induce the organization of the as-synthesized $\mathrm{MnFe}_{2} \mathrm{O}_{4}$ nanoparticles into novel amine-functionalized $\mathrm{Mn}$-Fe nanowires in good yields under basic condition and magnetic stirring for 24 hours. The precipitate was separated by centrifugation and washed with water/ethanol mixture to afford the 1-D Mn-Fe nanostructures.

\subsection{Characterization of the nanostructures}

The morphology of as-prepared $\mathrm{MnFe}_{2} \mathrm{O}_{4}$ nanoparticles was characterized by highresolution TEM, revealing their morphologies with an average diameter of $5 \mathrm{~nm}$ (Figure 1A). One drop of sample in ethanol suspension was added to the holey carbon-coated

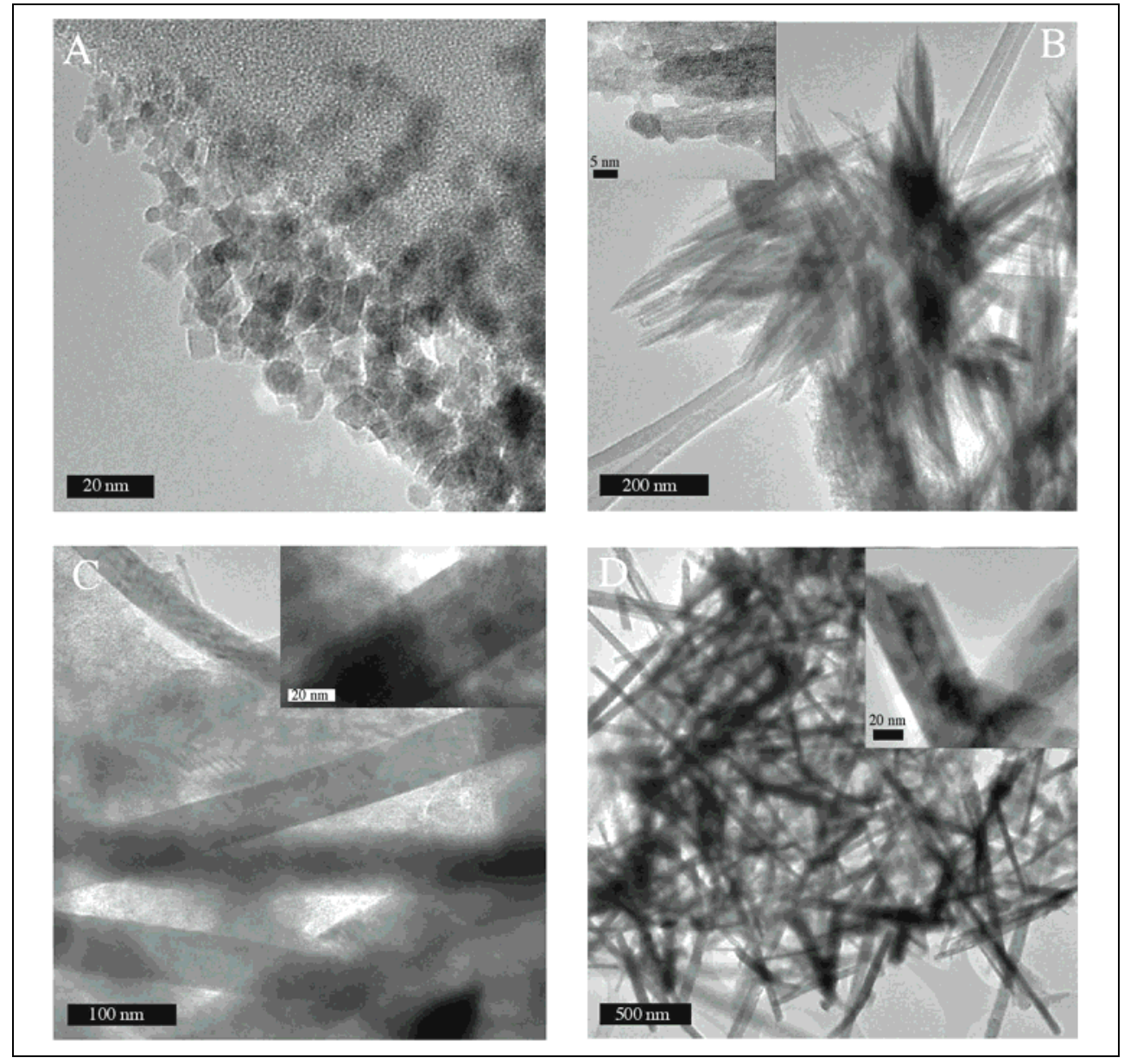

Fig. 1. High-resolution transmission electron microscopic images of (A) $\mathrm{MnFe}_{2} \mathrm{O}_{4}$ nanoparticles; (B) nanoneedles; (C) nanorods; and (D) nanowires. 
copper grid and was allowed to evaporate to dryness. For the prepared Mn-Fe nanostructures, TEM images revealed that they were in substantial amounts (Figures 1B-D). The nanoneedles possessed (Figure 1B) an average length of $400 \mathrm{~nm}$ and width of $8 \mathrm{~nm}$; while the nanorods possessed (Figure 1C) an average length of $800 \mathrm{~nm}$ and width of $30 \mathrm{~nm}$. For the nanowires, they possessed (Figure 1D) an average length of $1 \mu \mathrm{m}$ and width of $35 \mathrm{~nm}$.
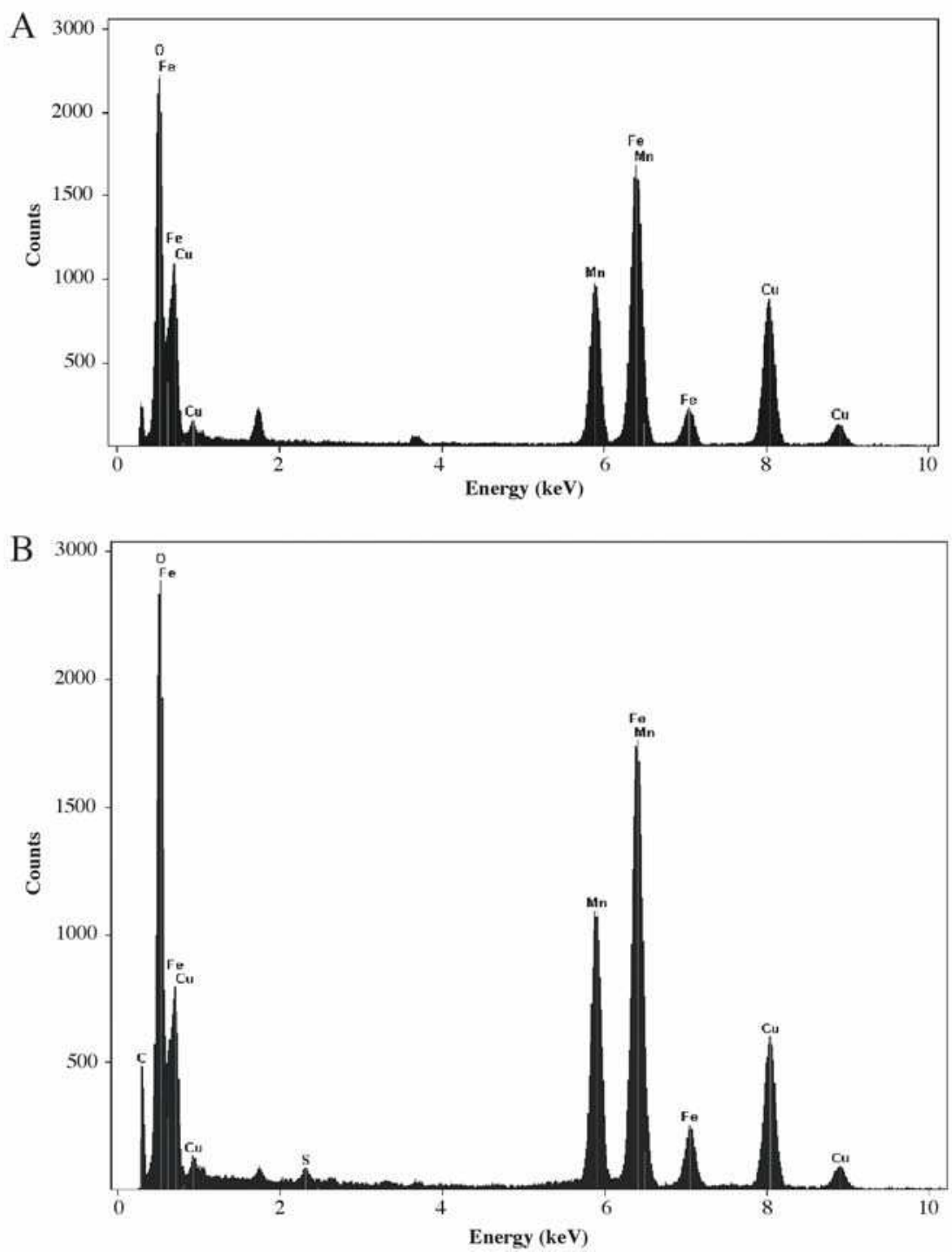

Fig. 2. Energy-dispersive X-ray spectroscopic analyses (on copper grid) of (A) $\mathrm{MnFe}_{2} \mathrm{O}_{4}$ nanoparticles and (B) $\mathrm{Mn}-\mathrm{Fe}$ nanowires. The obseved signals for $\mathrm{Cu}$ originated from the copper grid. 
In addition to the TEM characterization, inductively coupled plasma-optical emission spectroscopy (ICP-OES) and energy-dispersive X-ray (EDX) spectroscopy were employed for the determination of elemental contents $(\mathrm{Mn}, \mathrm{Fe}, \mathrm{S}, \mathrm{O}$ and $\mathrm{N})$ of the nanoarchitectures (Table 1, Figure 2). EDX measurements were performed by locating a region $(\sim 20 \mathrm{~nm} \times 20$ $\mathrm{nm}$ ) with substantial amount of materials on copper grid without carbon coating. By comparing between the EDX spectra of the $\mathrm{MnFe}_{2} \mathrm{O}_{4}$ nanoparticles (Figure 2A) and nanowires (Figure 2B), the spectrum of the nanowires revealed additional signals of sulfur and nitrogen as well as enhanced signals of carbon, originating from the attached cystamine linker. The observed EDX signal of copper, which originates from the TEM sample grid, has been omitted in the calculations of the elemental contents present in our nanostructures. The X-ray diffraction (XRD) analysis revealed that the $\mathrm{MnFe}_{2} \mathrm{O}_{4}$ nanoparticles exhibited several peaks corresponding to the characteristic interplanar spacings 220, 311, 400, 511 and 400 of the spinel structure with $2 \theta 31.5,35.0,42.4,56.2$ and 61.7 , respectively. These results are similar to the reported values in the literature (Aquino et al., 2002).

ICP-OES samples were dissolved in $2 \% \mathrm{HCl}$ solution with a few drops of $\mathrm{SnCl}_{2}$ solution. Iron absorption was observed at $238.20 \mathrm{~nm}$ while the manganese absorption was observed at $257.61 \mathrm{~nm}$. Although the separate measurements (Table 1) by ICP-OES and EDX occurred with the errors that are less than $1 \%$, there existed relatively large errors (0.3-48\%) when comparing the results obtained in both methods. Generally, ICP-OES is regarded as an accurate method to determine the metal ion concentrations while EDX spectroscopy is an evaluation of the existence of elements in a specific area on sample grid surface. The ratio of $\mathrm{Mn}: \mathrm{Fe}$ is approximately 1:2. From the $\mathrm{MnFe}_{2} \mathrm{O}_{4}$ nanoparticles to the nanowires, there was a trend in the quantitative ICP-OES measurements that both the Mn and Fe metal contents decrease slightly. Moreover, the sulfur and nitrogen contents originated from the cystamine linker appeared in the EDX measurement of the 1-D nanoarchitectures. These increased organic characteristics indicate that the amounts of linker play a crucial role in controlling the sizes of the nanostructures.

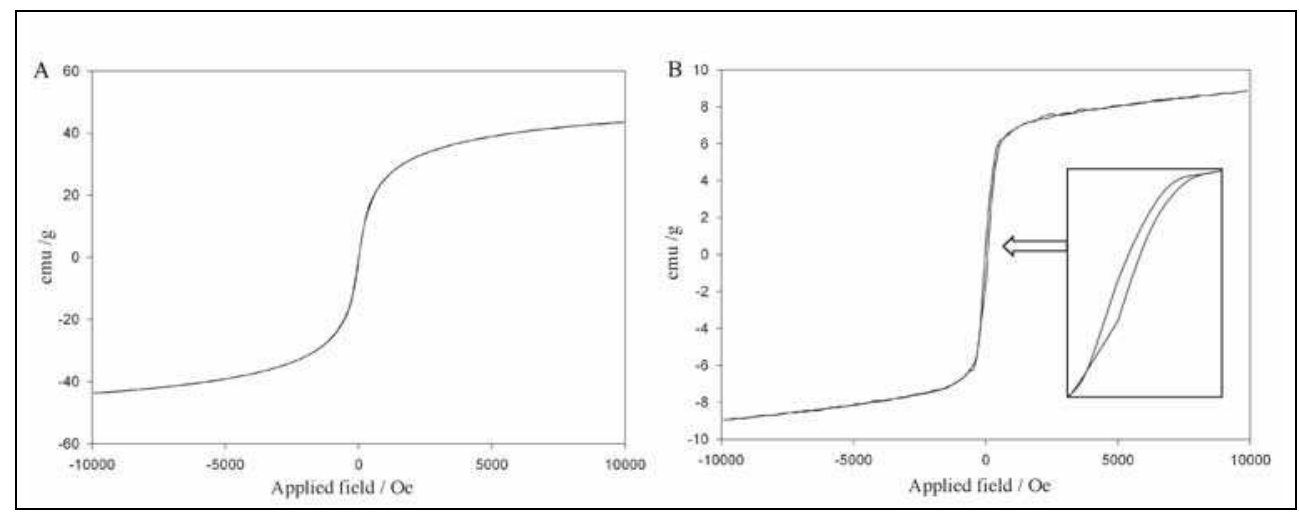

Fig. 3. VSM spectra of (A) $\mathrm{MnFe}_{2} \mathrm{O}_{4}$ nanoparticles and (B) Mn-Fe nanowires showing the difference in magnetic response.

The magnetic properties of the nanomaterials have been investigated using a vibrating sample magnetometer (VSM). The VSM spectra $(M-H)$ of magnetization (emu/g) versus magnetic field (Oe) are examined. Figure 3A shows a hysteresis loop of typical $\mathrm{MnFe}_{2} \mathrm{O}_{4}$ nanoparticles measured by sweeping the external field between -10000 to 10000 Oe at room 
temperature. The magnetization curve shows no remanemce or coercivity at room temperature, demonstrating the superparamagnetic character. Superparamagnetism is the responsiveness to an applied magnetic field without retaining any magnetism after removal of the applied magnetic field. The saturated magnetization value of $\mathrm{MnFe}_{2} \mathrm{O}_{4}$ nanoparticles is determined to be $43.7 \mathrm{emu} / \mathrm{g}$. On the other hand, Figure 3B shows a hysteresis loop of Mn-Fe nanowires measured by sweeping the external field between -10000 to 10000 Oe at room temperature. The magnetization curve shows that the coercivity and remanence are small at room temperature (Figure 3B inset). The saturated magnetization value of $\mathrm{Mn}-\mathrm{Fe}$ nanowires is determined to be $9.0 \mathrm{emu} / \mathrm{g}$. The decreased saturated magnetization value is in part due to the increasing thickness of organic coating layer of the nanowires. Other reasons are the presence of a magnetic dead or anti-ferromagnetic organic layer on the nanowire's periphery.

For high-density information storage, the superparamagnetic relaxation of magnetization direction in tiny magnetic data bits has to be avoided in order to keep the digital data stored for a desired period of time. For biomedical applications such as magnetic resonance imaging, hyperthermia, drug delivery, and catalysis, in contrast, superparamagnetic property of materials would be essential from which the materials do not retain any magnetization in the absence of an externally applied magnetic field. In our system, soft magnetized nanowires have been employed as contrast agents for magnetic resonance imaging.

\begin{tabular}{|c|c|c|c|c|c|c|c|c|}
\hline \multirow{2}{*}{ Mn-Fe structure } & average & average & \multicolumn{2}{|c|}{ ICP-OES } & \multicolumn{4}{|c|}{ EDX } \\
\cline { 4 - 9 } & $\mathrm{nm}$ & $\begin{array}{c}\text { length } \\
\mathrm{nm}\end{array}$ & $\mathrm{Mn} \%$ & $\mathrm{Fe} \%$ & $\mathrm{Mn} \%$ & $\mathrm{Fe} \%$ & $\mathrm{O} \%$ & $\mathrm{~N} \%$ \\
\hline nanoparticle & 5 & - & $\begin{array}{c}24.7 \pm \\
0.1\end{array}$ & $\begin{array}{c}40.6 \pm \\
0.2\end{array}$ & $\begin{array}{c}15.4 \pm \\
0.2\end{array}$ & $\begin{array}{c}40.7 \pm \\
0.3\end{array}$ & $\begin{array}{c}43.9 \pm \\
0.4\end{array}$ & - \\
\hline nanoneedle & 8 & 400 & $\begin{array}{c}20.4 \pm \\
0.1\end{array}$ & $\begin{array}{c}33.2 \pm \\
0.2\end{array}$ & $\begin{array}{c}10.6 \pm \\
0.1\end{array}$ & $\begin{array}{c}52.2 \pm \\
0.3\end{array}$ & $\begin{array}{c}32.9 \pm \\
0.3\end{array}$ & $\begin{array}{c}2.0 \pm \\
0.1\end{array}$ \\
\hline nanorod & \multirow{2}{*}{30} & 800 & $\begin{array}{c}19.7 \pm \\
0.1\end{array}$ & $\begin{array}{c}32.3 \pm \\
0.2\end{array}$ & $\begin{array}{c}20.0 \pm \\
0.3\end{array}$ & $\begin{array}{c}38.9 \pm \\
0.4\end{array}$ & $\begin{array}{c}36.5 \pm \\
0.5\end{array}$ & $\begin{array}{c}4.2 \pm \\
0.3\end{array}$ \\
\hline nanowire & 35 & 1000 & $\begin{array}{c}17.1 \pm \\
0.1\end{array}$ & $\begin{array}{c}28.2 \pm \\
0.1\end{array}$ & $\begin{array}{c}23.2 \pm \\
0.2\end{array}$ & $\begin{array}{c}39.9 \pm \\
0.2\end{array}$ & $\begin{array}{c}31.4 \pm \\
0.3\end{array}$ & $\begin{array}{c}5.5 \pm \\
0.3\end{array}$ \\
\hline
\end{tabular}

Table 1. Summarized results of ICP-OES and EDX measurements

\subsection{Magnetic resonance imaging}

For magnetic resonance imaging (MRI), the capability of nanoarchitectures to influence the T2 relaxation time was studied using a clinical $1.5 \mathrm{~T}$ whole-body MR system (Sonata, Siemens Symphony, Erlangen, Germany) with a standard human knee coil radio frequency coil for excitation and signal reception. Nanoarchitectures were diluted in distilled water at nanowire concentrations of 100, 10, 1 and $0.1 \mu \mathrm{g} / \mathrm{mL}$. For MR measurements, the nanomaterial suspensions $(1 \mathrm{~mL})$ were filled in $2 \mathrm{~mL}$ Eppendorf vials each. These vials were placed in a water bath. Sonication was applied for 10 min prior to MRI using at $35 \mathrm{kHz}$ in water at ambient temperature. The imaging sequence was a standard Carr-PurcellMeiboom-Gill pulse sequence with the following parameters: TR $=2000$ milisecond, TE range 30-960 milisecond, 32 echoes, FOV $=134 \times 67 \mathrm{~mm}^{2}$, matrix $=128 \times 64$, slice thickness 5 $\mathrm{mm}, \mathrm{NEX}=3 . \mathrm{T} 2$ relaxation times were calculated by a linear fit of the logarithmic ROI signal amplitudes versus TE. 
When a cylindrical magnetic nanorod segment is disk-shaped, its magnetization axis lies perpendicular to the rod axis. It also follows that if the segment is longer than its width, its axis of magnetization is parallel to the nanorod axis (Ferre et al., 1997). Therefore, the magnetic properties of nanostructures can be tuned over a wide range by tuning the aspect ratio of the magnetic block and its composition (Fert \& Piraux 1999). Experimentally, the T2 relaxivities (r2) for nanoneedles, nanorods, and nanowires were determined to be $20.81 \pm$ $0.58,8.10 \pm 0.31$, and $6.62 \pm 0.42 \mathrm{mM}^{-1} \mathrm{sec}^{-1}$, respectively (Figure 4). These values are at the lower end of the relaxivity of other iron oxide nanoparticle derivatives, such as VSOP-C184 has a r2 of $33 \mathrm{mM}^{-1} \mathrm{sec}^{-1}$ and SHU-555C (Supravist) has a r2 of $38 \mathrm{mM}^{-1} \mathrm{sec}^{-1}$ (Wang et al., 2001; Nitin et al., 2004; Lee et al., 2007; Lu et al., 2007; Lee et al., 2008). It is interesting to notice that though the iron concentration of nanoneedles is not very different to the other nanostructures, it has significantly higher MR relaxivity than the other nanostructures. It is known that MR relaxivity depends in part on the crystal lattice of the iron oxide. Our results suggest that the nanoneedles with higher MR relaxivity are majorly composed of iron oxide crystal lattice similar to those of the nanoparticles (Wang et al., 2001). The development of larger 1-D nanostructures leaded to lower MR relaxivities. Despite the slightly weaker MR relaxivity of the nanostructures developed in the current study, it is expected that the unique shape of these nanostructures can find applications for cell labeling, as drug carrier, magnetic separation of labeled cells and other biological entities, and also in the application of magnetic targeting (Alexiou et al., 2000; Pankhurst et al., 2003; Tartaj et al., 2003; Berry \& Curtis 2003). It may be possible to further modify the systems with the aim to increase their relaxivities. It has been reported that the doping of $\mathrm{Mn}$ into $\mathrm{Fe}_{3} \mathrm{O}_{4}$ can also increase the MR

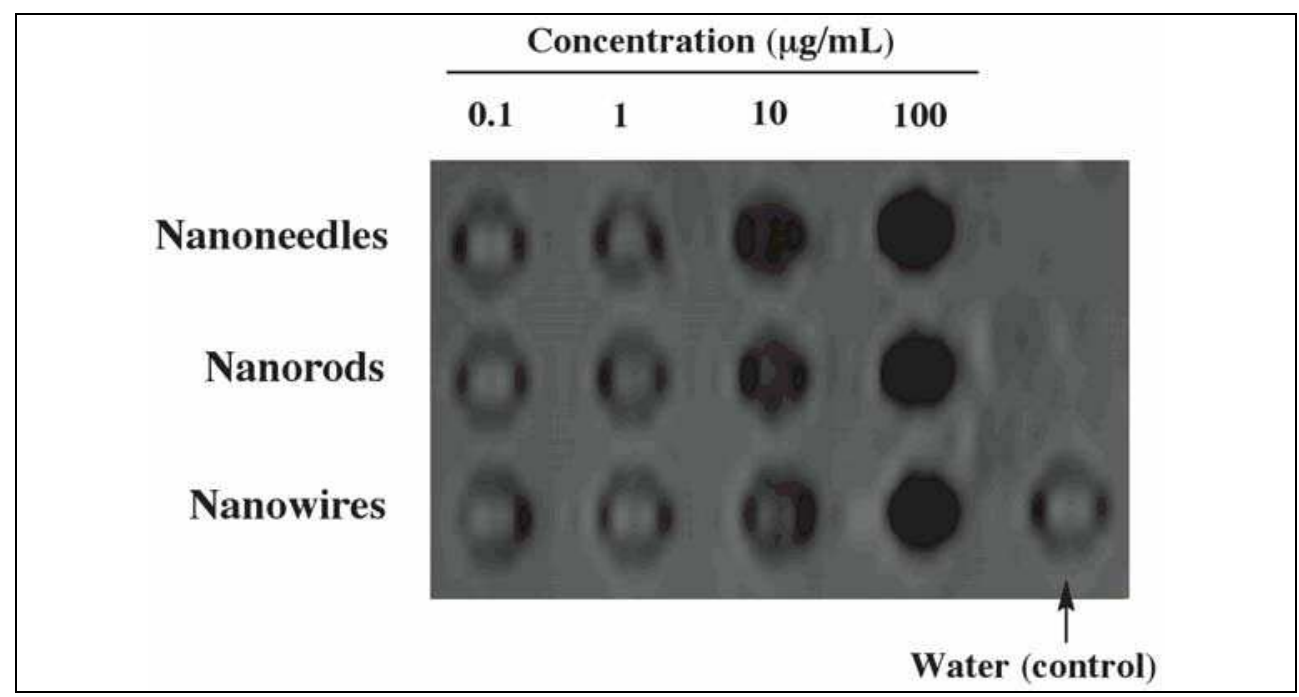

Fig. 4. Spin echo MR image of the Mn-Fe nanostructure suspensions obtained at 1.5 Tesla with time of repetition (TR) 2000 millisecond and time of echo (TE) of 960 millisecond. All the Mn-Fe nanostructures with concentration of $100 \mu \mathrm{g} / \mathrm{mL}$ decrease the MRI signal to background signal (dark contrast). Mn-Fe nanostructures with concentration of $10 \mu \mathrm{g} / \mathrm{mL}$ decrease the MRI signal substantially, though less so with nanorods. Compared to the water signal, contrast due to $1 \mu \mathrm{g} / \mathrm{mL}$ nanostructures is just detectable. 
relaxivity as compared with the pure iron oxide counterpart (Lee et al., 2007). For in vivo tissue contrast, the weaker MR relaxivity can be compensated by using $T 2 *$ MRI sequence and higher magnetic field such as 3 Tesla or 7 Tesla.

The nanowires were incubated with RAW264.7 cells followed by Prussian blue staining. The results indicated that the $\mathrm{Mn}-\mathrm{Fe}$ nanowires were effectively incorporated into RAW264.7 cells without the addition of any transfecting agent (e.g., liposomes) (Figure 5). Figures 5B-5D reveal the optical microscopic images of the RAW264.7 cells incubated with nanowires for 2 hours at the concentration of 10,50,100 $\mu \mathrm{g} / \mathrm{mL}$ respectively. As increasing

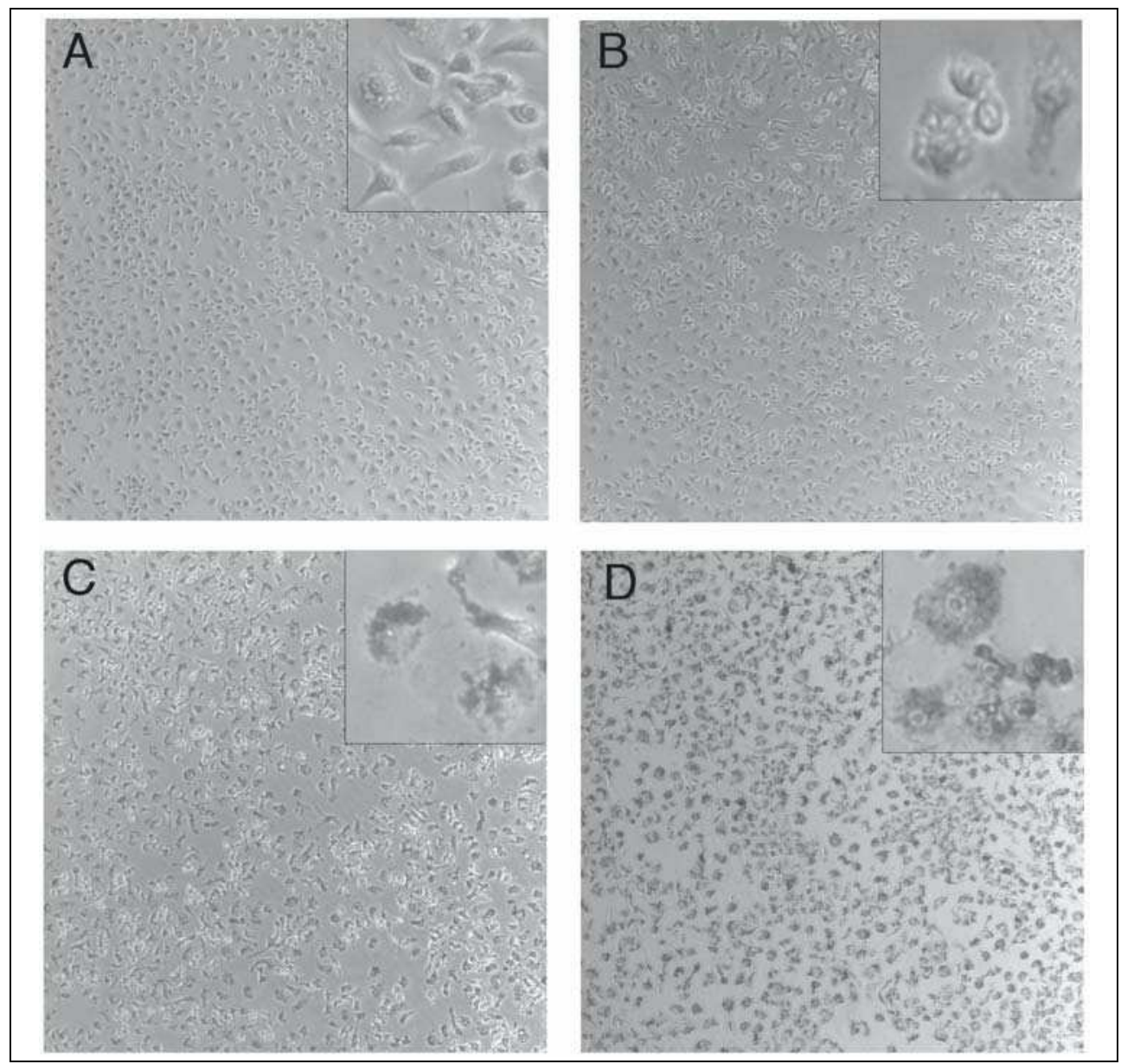

Fig. 5. Optical microscope images of the Raw264.7 cells [Original magnification: $100 \times$ ]: (A) Control cells without the labeling of nanowires. (B)-(D) Cells incubated with nanowires for 2 hours at the concentration of 10,50,100 $\mathrm{g} / \mathrm{mL}$, respectively. Prussian blue staining was carried out. As increasing the labeling concentration with nanowires, increased amounts of the nanowire uptake are observed as shown in the blue-stained part inside the cells. For (C) and (D), the cell labeling efficacies with the nanowires are approximately $100 \%$. 
the labeling concentration with nanowires, increased amounts of the nanowire uptake were observed as in the blue-stained part inside the cells. At the nanowire concentrations of 50 and $100 \mu \mathrm{g} / \mathrm{mL}$ (Figures 5C and 5D), the cell labeling efficacies with the nanowires were approximately $100 \%$.

TEM analysis was also performed to confirm the location of nanowires inside the RAW264.7 cells. For the TEM analysis, specimens were fixed in $2.5 \%$ glutaraldehyde and $2 \%$ paraformaldehyde in $0.1 \mathrm{M}$ cacodylate buffer ( $\mathrm{pH} 7.2$ ) containing $0.05 \% \mathrm{CaCl}_{2}$ for 2 hours at room temperature, followed by post-fixation in $2 \%$ osmium tetroxide in the same buffer solution for 2 hours at room temperature. After dehydration and embedded in Spurr's resin, ultra-thin sections $(80 \mathrm{~nm})$ were cut before examined under a FEI/Philips Tecnai 12 TEM operated at $80 \mathrm{kV}$. TEM results demonstrated that the nanowires were located within the lyzosome and cell vesicles (Figure 6). No obvious sub-cellular superstructure injury and cell apoptosis was observed. However, modest amount of the nanoparticles were observed inside the lyzosome and cell vesicles, a result which indicates that the nanostructures might be susceptible to enzymatic degradation in the slightly acidic lyzosome environment. It is also expected that some nanowires incorporated in the cells were fragmented or partially cut during the preparation of the ultra-thin section for TEM.

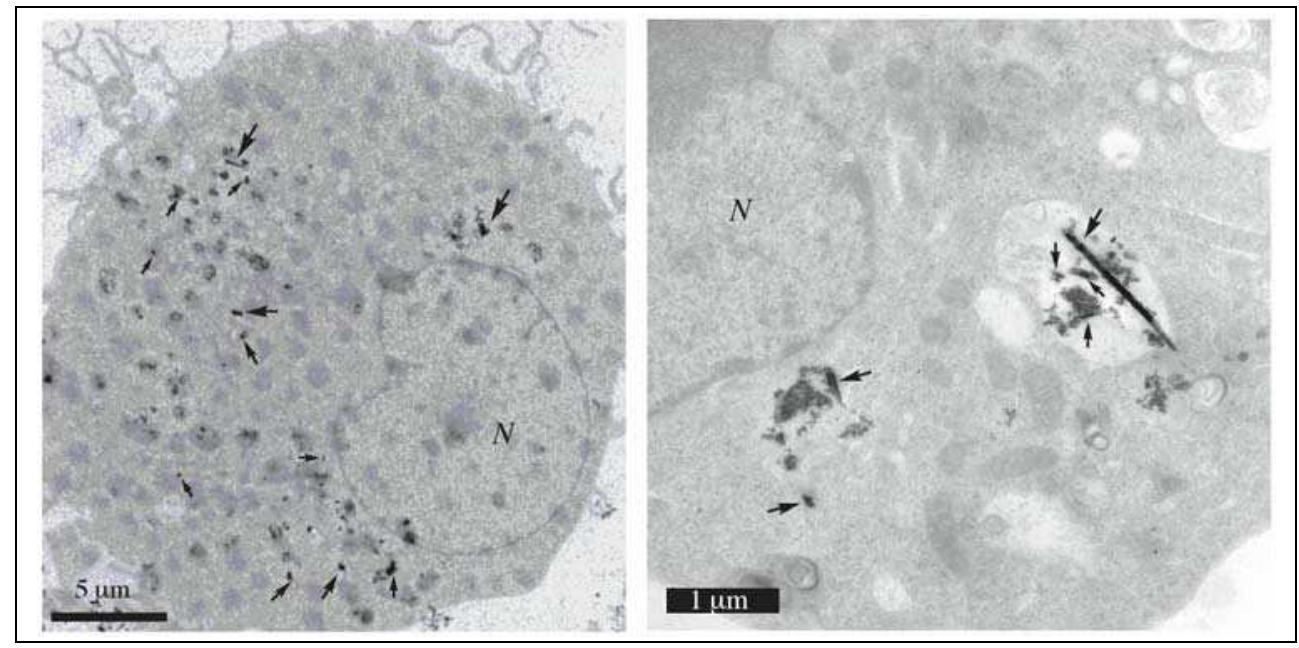

Fig. 6. TEM images of the nanowires-labeled RAW264.7cells. The arrow denotes some of the nanowires present in the lysosomes and vesicles.

It has been demonstrated that certain biocompatible synthetic materials with amine functional peripheries could enhance the degree of cell adhesion and transfection (Pollard et al., 1998; Wang et al., 2009). As a result, our reported Mn-Fe nanostructures which contain free amines would be beneficial not only to the macrophage cells but also can extend their labeling efficacy to other cell lines.

To assess the biocompatibility of the nanostructures, after RAW264.7 cells incubated with $0.1,1,10,50,100 \mu \mathrm{g} / \mathrm{mL}$ nanowires for 2 hours, Trypan blue exclusion assay (Sigma T6146) was performed to assess the viability of the cells. To assess the cell proliferation potential post labeling, RAW264.7 cells were cultured in 96-well plate at the density of 2500 cell/well 
with DMEM including 10\% FCS. After labeling cells with $0.1,1,10,50$ or $100 \mu \mathrm{g} / \mathrm{mL}$ nanowires for 2 hours, nanowires were removed from the plate and PBS was used to rinse the residual nanostructures. Fresh DMEM including 10\% FCS was added again for normal cell growth. 3-[4,5-Dimethylthiazol-2-yl]-2,5-diphenyl tetrazolium bromide (MTT) assay was performed to detect the proliferation of the nanowire-labeled RAW264.7 cells.

The Trypan blue exclusion assay results and MTT assay results are shown in Figure 7. RAW264.7 cell viability was not significantly affected from the labeling concentration of 0.1 up to $50 \mu \mathrm{g} / \mathrm{mL}$ with nanowires, and no apparent growth inhibition of RAW264.7 cells was observed after labeling up to $50 \mu \mathrm{g} / \mathrm{mL}$ of nanowires (inclusive). These results revealed the satisfactory safety profiles of these nanostructures.
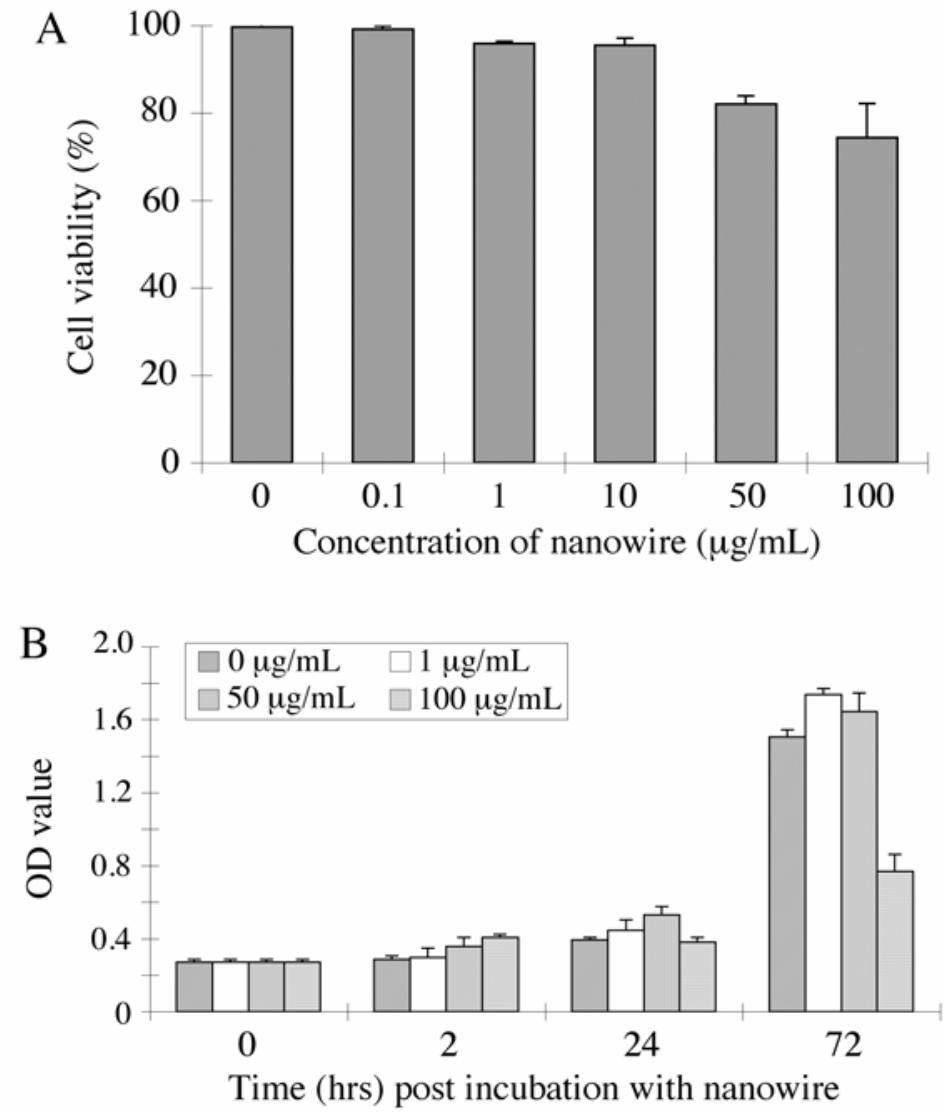

Fig. 7. The Trypan blue exclusion assay and MTT assay results. RAW264.7 cells were incubated with $0.1,1,10,50,100 \mu \mathrm{g} / \mathrm{mL}$ of nanowires for 2 hours. Satisfactory biocompatibility is shown from the concentration of 0.1 to $50 \mu \mathrm{g} / \mathrm{mL}$. At $100 \mu \mathrm{g} / \mathrm{mL}$, cell death and cell proliferation inhibition was observed. 


\section{Conclusion}

In summary, the manganese-doped iron oxide nanoparticles are capable to organize into one-dimensional magnetic $\mathrm{Mn}$-Fe nanostructures of different sizes with cystamine. The use of these materials which are employed as the cell-labeling agent for magnetic resonance imaging (MRI), has been explored. All nanoarchitectures demonstrate remarkable magnetic resonance $T 2$ relaxivities. The cell viability test and growth curve reveal the satisfactory safety profiles of these nanostructures. This method represents an efficient and facile way to prepare novel functional nanoarchitectures for potential use in magnetic separation of labeled cells and other biological entities, magnetic resonance imaging, carriers of therapeutic molecules and magnetic targeting, and radio frequency therapy of tumours via hyperthermia (Alexiou et al., 2000; Berry \& Curtis 2003; Pankhurst et al., 2003; Tartaj et al., 2003). Eventually, nanoarchitectures of specific sizes can be potentially obtained by this method and used as MRI contrast agents. The labeling efficacies of these nanostructures can be investigated with different cell types such as inflammation cells and liver cells (Du et al., 2007), etc. The comparative study on the use of both magnetic nanoparticles and nanowires as effective, biocompatible MRI contrast agents for different cell lines should be further investigated.

\section{References}

Alexiou, C.; Arnold, W.; Klein, R. J.; Parak, F. G.; Hulin, P.; Bergemann, C.; Erhardt, W.; Wagenpfeil, S. \& Lübbe, A. S. (2000). Locoregional cancer treatment with magnetic drug targeting. Cancer Res., 60, 6641-6648

Allwood, D. A.; Xiong, G.; Cooke, M. D.; Faulkner, C. C.; Atkinson, D.; Vernier, N. \& Cowburn, R. P. (2003). Submicrometer ferromagnetic NOT gate and shift register. Science, 296, 2003-2006

Aquino, R.; Tourinho, F. A.; Itri, R.; Lara, M. C. F. L. \& Depeyrot, J. (2002). Size control of $\mathrm{MnFe}_{2} \mathrm{O}_{4}$ nanoparticles in electric double layered magnetic fluid synthesis. J. Mag. Mag. Mater., 252, 23-25

Berry, C. C. \& Curtis, A. S. G. (2003). Functionalisation of magnetic nanoparticles for applications in biomedicine. J. Phys. D: Appl. Phys., 36, R198-R206

Chen, M.; Searson, P. C. \& Chien, C. L. (2003). Micromagnetic behavior of electrodeposited Ni/Cu multilayer nanowires. J. Appl. Phys., 93, 8253-8255

Chen, M.; Sun, L.; Bonevich, J. E.; Reich, D. H.; Chien, C. L. \& Searson, P. C. (2003). Tuning the response of magnetic suspensions. Appl. Phys. Lett., 82, 3310-3312

Cohen-Karni, T.; Timko, B. P.; Weiss, L. E. \& Lieber, C. M. (2009). Flexible electrical recording from cells using nanowire transistor arrays. Proc. Natl. Acad. Sci. USA, 106, 7309-7313

Corot, C.; Robert, P.; Idée, J. M. \& Port, M. (2006). Recent advances in iron oxide nanocrystal technology for medical Imaging. Adv. Drug Deliv. Rev., 58, 1471-1504

Darques, M.; Spiegel, J.; De la Torre Medina, J.; Huynen, I. \& Piraux, L. (2009). Ferromagnetic nanowire-loaded membranes for microwave electronics. J. Magn. Magn. Mater., 321, 2055-2065

Deng, H.; Li, X.; Peng, Q.; Wang, X.; Chen, J. \& Li, Y. (2005). Monodispersed magnetic single-crystal ferrite microspheres. Angew. Chem., Int. Ed., 44, 2782-2785 
Doudin, B.; Blondel, A. \& Ansermet, J.-Ph. (1996). Arrays of multilayered nanowires. J. Appl. Phys., 79, 6090-6094

Du, L.; Chen, J.; Qi, Y.; Li, D.; Yuan, C.; Lin, M. C.; Yew, D. T.; Kung, H.-F.; Yu, J. C. \& Lai, L. (2007). Preparation and biomedical application of a non-polymer coated superparamagnetic nanoparticle. Int. J. Nanomed., 2, 805-812

Fang Z. \& Kelley, S. O. (2009). Direct electrocatalytic mRNA detection using PNA-nanowire sensors. Anal. Chem., 81, 612-617.

Ferré, R.; Ounadjela, K.; George, J. M.; Piraux, L. \& Dubois, S. (1997). Magnetization processes in nickel and cobalt electrodeposited nanowires. Phys. Rev. B, 56, 1406614075

Fert, A. \& Piraux, L. (1999). Magnetic nanowires. J. Magn. Magn. Mater., 200, 338-358

Fortin, J. P.; Wilhelm, C. Servais, J.; Ménager, C.; Bacri, J. C. \& Gazeau, F. (2007). Size-sorted anionic iron oxide nanomagnets as colloidal mediators for magnetic hyperthermia. J. Am. Chem. Soc., 129, 2628-2635

García, J. M. \& Miltat, A. T. J. (2002). MFM imaging of nanowires and elongated patterned elements. J. Magn. Magn. Mater., 249, 163-169

Grubbs, R. B. (2007). Solvent-tuned structures. Nat. Mater., 6, 553-555

Hangarter, C. M.; Rheem, Y.; Yoo, B.; Yang, E.-H. \& Myung, N. V. (2007). Hierarchical magnetic assembly of nanowires. Nanotechnology, 18, article number 205305

Lee, J.-H.; Huh, Y. M.; Jun, Y.-W.; Seo, J.-W.; Jang, J.-T.; Song, H.-T.; Kim, S.; Cho, E.-J.; Yoon, H.-G.; Suh, J.-S. \& Cheon, J. (2007). Artificially engineered magnetic nanoparticles for ultra-sensitive molecular imaging. Nat. Med., 13, 95-99

Lee, H.-Y.; Lee, S.-H.; Xu, C.; Xie, J.; Lee, J.-H.; Wu, B.; Koh, A. L.; Wang, X.; Sinclair, R.; Wang, S. X.; Nishimura, D. G.; Biswal, S.; Sun, S.; Cho, S. H. \& Chen, X. (2008). Synthesis and characterization of PVP-coated large core iron oxide nanoparticles as an MRI contrast agent. Nanotechnology, 19, 165101-165106

Leung, K. C.-F.; Wang, Y.-X.; Wang, H.-H. \& Chak, C.-P. (2008). Novel one-dimenstional $\mathrm{Mn}-\mathrm{Fe}$ oxide nanowires for cell labeling and magnetic resonance imaging. IEEE Proceedings of the $5^{\text {th }}$ International Conference on Information Technology and Application in Biomedicine, 193-195, Shenzhen, China, May 30-31, 2008, IEEE

Leung, K. C.-F.; Wang, Y.-X. J.; Wang, H.-H.; Xuan, S.; Chak, C.-P. \& Cheng, C. H. K. (2009). Biological and magnetic contrast evaluation of shape-selective Mn-Fe nanowires. IEEE Trans. Nanobiosci. 8, 192-198.

Love, J. C.; Urbach, A. R.; Prentiss, M. G. \& Whitesides, G. M. (2003). Three-dimensional self-assembly of metallic rods with submicron diameters using magnetic interactions. J. Am. Chem. Soc., 125, 12696-12697

Lu, C.-W.; Hung, Y.; Hsiao, J.-K.; Yao, M.; Chung, T.-H.; Lin, Y. S.; Wu, S.-H.; Hsu, S.-C.; Liu, H.-M.; Mou, C.-Y.; Yang, C.-S.; Huang, D.-M. \& Chen, Y.-C. (2007). Bifunctional magnetic silica nanoparticles for highly efficient human stem cell labelling. Nano Lett., 7, 149-154

Lübbe, A. S.; Alexiou, C. \& Bergemann, C. (2001). Clinical applications of magnetic drug targeting. J. Surg. Res., 95, 200-206

Meier, J.; Doudin, B. \& Ansermet, J.-Ph. (1996). Magnetic properties of nanosized wires. J. Appl. Phys., 79, 6010-6012 
Mitragotri, S. \& Lahann, J. (2009). Physical approaches to biomaterial design. Nat. Mater., 8, $15-23$

Nam, J.-M.; Thaxton, C. S. \& Mirkin, C. A. (2003). Nanoparticle-based bio-bar codes for the ultrasensitive detection of proteins. Science, 301, 1884-1886

Nielsch, K.; Hertel, R.; Wehrspohn, R. B.; Barthel, J.; Kirschner, J.; Gösele, U.; Fischer, S. F. \& Kronmüller, H. (2002). Switching behavior of single nanowires inside dense nickel nanowire arrays. IEEE Trans. Magn., 38, 2571-2573

Nitin, N.; LaConte, L. E. W.; Zurkiya, O.; Hu, X. \& Bao G. (2004). Functionalization and peptide-based delivery of magnetic nanoparticles as an intracellular MRI contrast agent. J. Biol. Inorg. Chem., 9, 706-712

Pankhurst, Q. A.; Connolly, J.; Jones, S. K. \& Dobson, J. (2003). Applications of magnetic nanoparticles in biomedicine. J. Phys. D: Appl. Phys., 36, R167-R181

Park, J.-H.; von Maltzahn, G.; Zhang, L.; Derfus, A. M.; Simberg, D.; Harris, T. J.; Ruoslahti, E.; Bhatia, S. N. \& Sailor, M. J. (2009). Systematic surface engineering of magnetic nanoworms for in vivo tumor targeting. Small, 5, 694-700

Pollard, H.; Remy, J.-S.; Loussouarn, G.; Demolombe, S.; Behr, J.-P. \& Escande, D. (1998). Polyethylenimine but not cationic lipids promotes transgene delivery to the nucleus in mammalian cells. J. Biol. Chem., 273, 7507-7511

Ponhan, W. \& Maensiri, S. (2009). Fabrication and magnetic properties of electrospun copper ferrite $\left(\mathrm{CuFe}_{2} \mathrm{O}_{4}\right)$ nanofibers. Solid State Sci., 11, 479-484

Redl, F. X.; Cho, K. S.; Murray, C. B. \& O'Brien, S. (2003). Three-dimensional binary superlattices of magnetic nanocrystals and semiconductor quantum dots. Nature, 423, 968-971

Skomski, R. (2003). Nanomagnetics. J. Phys. Condens. Matt., 15, R841-R896

Sousa, M. H.; Tourinho, F. A.; Depeyrot, J.; da Silva, G. J. \& Lara, M. C. F. L. (2001). New electric double-layered magnetic fluids based on copper, nickel, and zinc ferrite nanostructures. J. Phys. Chem. B, 105, 1168-1175

Stephanopoulos, N.; Solis, E. O. P. \& Stephanopoulos, G. (2005). Nanoscale process systems engineering: toward molecular factories, synthetic cells, and adaptive devices. AIChE J., 51, 1858-1869

Tang, Z.; Kotov, N. A. \& Giersig, M. (2002). Spontaneous organization of single CdTe nanoparticles into luminescent nanowires. Science, 297, 237-240

Tartaj, P.; del Puerto Morales, M.; Veintemillas-Verdaguer, S.; Teresita González-Carreño, T. \& Serna, C. J. (2003). The preparation of magnetic nanoparticles for applications in biomedicine. J. Phys. D: Appl. Phys., 36, R182-R197

Thurn-Albrecht, T.; Schotter, J. ; Kastle, G. A. ; EmLey, N. ; Shibauchi, T. ; Krusin-Elbaum, L.; Guarini, K.; Black, C. T.; Tuominen, M. T. \& Russell, T. P. (2000). Ultrahigh-density nanowire arrays grown in self-assembled diblock copolymer templates. Science, 290, 2126-2129

Wang, H.-H.; Wang, Y.-X. J.; Leung, K. C.-F.; Au, D. W. T.; Xuan, S.; Chak, C.-P.; Lee, S. K. M.; Sheng, H.; Zhang, G.; Qin, L.; Griffith, J. F. \& Ahuja, A. T. (2009). Durable mesenchymal stem cell labelling using polyhedral superparamagnetic iron oxide nanoparticles. Chem. Eur. J., 15, 12417-12425. 
Wang, Y.-X. J.; Hussain, S. M. \& Krestin, G. P. (2001). Superparamagnetic iron oxide contrast agents: physicochemical characteristics and applications in MR imaging. Eur. Radiology, 11, 2319-2331

Whitney, T. M.; Jiang, J. S.; Searson, P. C. \& Chien, C. L. (1993). Fabrication and magnetic properties of arrays of metallic nanowires. Science, 261, 1316-1319

Wilhelm, C. \& Gazeau, F. (2008). Universal cell labelling with anionic magnetic nanoparticles. Biomaterials, 29, 3161-3174

Wu, H.; Zhang, R.; Liu, X.; Lin, D. \& Pan, W. (2007). Electrospinning of Fe, Co, and Ni nanofibers: synthesis, assembly, and magnetic properties. Chem. Mater., 19, 35063511

Xia, Y.; Rogers, J. A.; Paul, K. E. \& Whitesides, G. M. (1999). Unconventional methods for fabricating and patterning nanostructures. Chem. Rev., 99, 1823-1848 


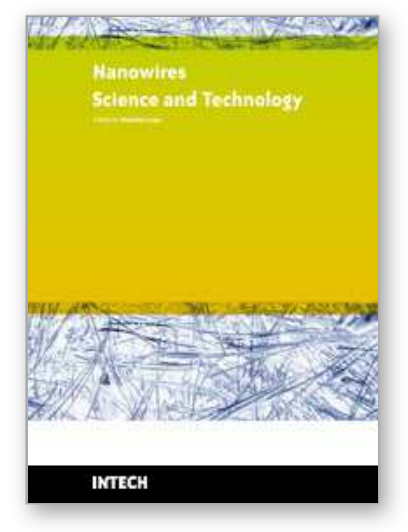

\author{
Nanowires Science and Technology \\ Edited by Nicoleta Lupu
}

ISBN 978-953-7619-89-3

Hard cover, 402 pages

Publisher InTech

Published online 01, February, 2010

Published in print edition February, 2010

This book describes nanowires fabrication and their potential applications, both as standing alone or complementing carbon nanotubes and polymers. Understanding the design and working principles of nanowires described here, requires a multidisciplinary background of physics, chemistry, materials science, electrical and optoelectronics engineering, bioengineering, etc. This book is organized in eighteen chapters. In the first chapters, some considerations concerning the preparation of metallic and semiconductor nanowires are presented. Then, combinations of nanowires and carbon nanotubes are described and their properties connected with possible applications. After that, some polymer nanowires single or complementing metallic nanowires are reported. A new family of nanowires, the photoferroelectric ones, is presented in connection with their possible applications in non-volatile memory devices. Finally, some applications of nanowires in Magnetic Resonance Imaging, photoluminescence, light sensing and field-effect transistors are described. The book offers new insights, solutions and ideas for the design of efficient nanowires and applications. While not pretending to be comprehensive, its wide coverage might be appropriate not only for researchers but also for experienced technical professionals.

\title{
How to reference
}

In order to correctly reference this scholarly work, feel free to copy and paste the following:

Ken Cham-Fai Leung and Yi-Xiang J. Wang (2010). Mn-Fe Nanowires Towards Cell Labeling and Magnetic Resonance Imaging, Nanowires Science and Technology, Nicoleta Lupu (Ed.), ISBN: 978-953-7619-89-3, InTech, Available from: http://www.intechopen.com/books/nanowires-science-and-technology/mn-fenanowires-towards-cell-labeling-and-magnetic-resonance-imaging

\section{INTECH}

open science | open minds

\section{InTech Europe}

University Campus STeP Ri

Slavka Krautzeka 83/A

51000 Rijeka, Croatia

Phone: +385 (51) 770447

Fax: +385 (51) 686166

www.intechopen.com

\section{InTech China}

Unit 405, Office Block, Hotel Equatorial Shanghai

No.65, Yan An Road (West), Shanghai, 200040, China

中国上海市延安西路65号上海国际贵都大饭店办公楼405单元

Phone: +86-21-62489820

Fax: +86-21-62489821 
(C) 2010 The Author(s). Licensee IntechOpen. This chapter is distributed under the terms of the Creative Commons Attribution-NonCommercialShareAlike-3.0 License, which permits use, distribution and reproduction for non-commercial purposes, provided the original is properly cited and derivative works building on this content are distributed under the same license. 